\section{AL-AZHAR Dental Journal}

F $\quad \mathrm{O} \quad \mathrm{r}$
The Official Publication of The Faculty of Dental Medicine For Girls, Al-Azhar University Cairo, Egypt.

Print ISSN 2537-0308 • Online ISSN 2537-0316

ADJ-for Girls, Vol. 7, No. 4, October (2020) — PP. 599:605

\title{
Effect of Mesenchymal Stem Cell Injection on Healing Outcome in Secondary Cleft Lip Correction
}

\section{Somaya M. Zakeeri", Hatem H. Al Ahmady², Nahed M. Adly ${ }^{3}$,Ahmed M. Zidan ${ }^{4}$, Ahmed F. Abd Alzeem ${ }^{5}$}

Codex : 74/20.10

azhardentj@azhar.edu.eg

http://adjg.journals.ekb.eg

DOI: $10.21608 /$ adjg.2020.23227.1229

Oral Medicine \& Surgical Sciences (Oral Medicine, Oral \& Maxillofacial Surgery, Oral Pathology, Oral Biology)

\begin{abstract}
Purpose: This study aimed to evaluate the effect of intraoperative mesenchymal stem cell injection on healing outcome in secondary cleft lip correction. Patients and Methods: A total of ten patients with secondary cleft lip deformities who needed secondary cleft lip repair were included in this study. The patients were divided equally into two groups: group I (study group) were subjected to secondary cleft lip repair with immediate intraoperative bone marrow mesenchymal stem cells injection (BM-MSCs), group II (control group) who didn't receive any type of injection neither during surgery nor after. The healing out come and scar progression were recorded through photographs and Ultrasonography (US). Results: Group I showed higher rate in primary healing outcome than that of group II. The Ultrasound revealed statistically significant difference in scar progression in both groups. Group I showed statistically significant difference in scar measurements across time than group II in $p<0.01$. Conclusion: Bone marrow mesenchymal stem cell injection in cleft lip correction has a good effect on primary healing outcome and scar progression.
\end{abstract}

Bone Marrow Mesenchymal

Stem Cell, Ultrasonography

- Paper extracted from Master thesis titled "Effect of Mesenchymal Stem Cell Injection on Healing Outcome in Secondary Cleft Lip Correction"

1. Demonstrator at Oral and Maxillofacial Surgery Department, Faculty of Oral and Dental Medicine for Girls, Al-Azhar University, Cairo, Egypt.

2. Professors of Oral and Maxillofacial Surgery, Faculty of Oral and Dental medicine for Girls, Al-Azhar University, Cairo, Egypt.

3. Lecturer of Oral and Maxillofacial Surgery, Faculty of Oral and Dental medicine for Girls, Al-Azhar University, Cairo, Egypt.

4. Lecturer of Diagnostic Radiology, Faculty of Medicine for Boys, Al-Azhar University, Cairo, Egypt.

5. Assistant researcher at Orodental Genetics Department, Human Genetic Division, National Research Center, Cairo, Egypt.

* Corresponding author email: somayazakeer.26@azhar.edu.eg 


\section{INTRODUCTION}

Although the great advances that have been achieved in the primary the cleft lip and palate deformity correction, the secondary lip and nasal deformities still always occur in most of the patients ${ }^{(1)}$. Surgical secondary corrections of soft tissue deformities caused by scars after the primary surgeries are almost always necessary ${ }^{(2)}$. Many factors affecting the secondary deformities including the type of the cleft, techniques of surgical reconstruction and timing of primary lip repair ${ }^{(3,4)}$.

The cleft lip deformities can be classified into minor and major deformities ${ }^{(5)}$. Minor deformities are unfavorable scars, interrupted white roll, lip length asymmetry, shallow oral vestibule and irregularities in the skin. Major deformities are loss of muscle reconstruction and abnormal insertion, lip length asymmetry with nasal deformity, long or short lip and loss of function. Cleft lip nasal deformities are depressed nasal tip, alar web, eversion of alar base, nasal obstruction and shortened columella ${ }^{(6-8)}$

The wound healing may cause the formation of fibrotic tissues called scar ${ }^{(9)}$. lip scarring is of major importance due to its psychological and sociable effect on cleft patients. It involves more than one overlapping, coordinated phases including inflammation phase, proliferation phase, and remodeling phase ${ }^{(10,11)}$. Current therapies for scar management are frequently used with little effect. The prevention of pathologic scarring is more effective through mechanical relief of incisions and proper surgical technique, which may affect the scar width and hypertrophy ${ }^{(12)}$.

One of the most important upcoming methods in the treatment and prevention of facial scars is the Mesenchymal Stem Cells (MSCs). MSCs were first described by Friedenstein and colleagues in 1976 (13). MSCs are multi-potent, self-renewing cells presented in several tissues, including the adipose tissue, bone marrow umbilical cord, and placenta. These cells are capable of generating different mesenchymal cell types, traditional adipocytes, chondrocytes, and osteocytes, smooth muscle cells and cardiomyocytes ${ }^{(14,15)}$. It has a reparative effect through paracrine signaling releasing biologically active molecules that affect cell migration, proliferation, and survival of the surrounding cells. It can have a role in the inflammatory, proliferative, and remodeling phases of wound healing ${ }^{(16-19)}$.

The healthy and reconstructed lipcan be visualized and evaluated through the ultrasonography. Highfrequency ultrasound examination has been recommended as a non-invasive method to assess scar thickness. It capable of producing valid and reproducible results in both, healthy and scarred tissue. Many trials and case reports have been conducted to assess the reliability of the ultrasound imaging (20-22) .

The upper lip tissue is divided into five layers: The first layer is the skin epidermis. The second layer is formed by skin and philtrum and philtrum columns, and the superficial layer of the orbicularis oris muscle. The third layer containing the orbicularis oris muscle deep layer. The submucosa of the upper lip tissue and upper lip artery are forming the fourth layer. The fifth layer is the mucous layer of the upper lip tissue. ${ }^{(23)}$.This study was performed where the secondary cleft lip correction in both groups was done with immediate intraoperative BM-MSCs injection in group I with clinical and ultrasonographic follow up.

\section{PATIENTS AND METHODS}

\section{Subjects}

A total of 10 cleft lip patients who were complaining from secondary cleft lip and/or nose deformities (4male and 6 female) were included in this study. They were selected from the outpatient clinic of the Al Azhar cleft Lip and Palate Center in the Oral and Maxillofacial Surgery Department at Al Azhar University, Faculty of Oral and Dental Medicine between 2017-2019. Ethical approval to the operation on the patients was obtained in 
accordance with guidelines from the research ethical committee of Faculty of Oral and Dental Medicine Al-Azhar University. Individuals who were subjected to previous secondary cleft lip repair were excluded. The patients were divided equally into two groups: group I patients were subjected to secondary cleft lip correction with or without nose revision and immediate intraoperative BMMSCs injection. Group II patients were subjected to secondary cleft lip correction with or without nose revision without any type of injection.

\section{Methods}

Secondary cleft lip correction was applied to all patients in both groups. The design of cutting and planning was primarily depending on the scar shape and direction. After infiltrating the lip with local anesthesia, the scar was excised to the extent that allows symmetrical lip closure according to the preoperative planning. The orbicularis oris muscle and nasolabial muscle bundles were dissected from their wrong attachment and relocated using the functional repair method concept. Some patients needed open and/or closed rhinoplasty. In group I bone marrow aspirate was harvested from the anterior iliac crest then the mononuclear cell layer containing the bone marrow stem cells was freshly prepared by density gradient centrifugation method technique ${ }^{(24)}$. Intraoperative injection of the BMMSCs into the subcutaneous, intramuscular layer and around the incision line immediately after skin wound closure.

\section{Equipment}

LOGIQ S6 (GE Healthcare, USA) ultrasound system. A $12 \mathrm{MHz}$ linear-array transducer was used with ultrasound gel as a coupling medium.

\section{Measurements}

All examinations were performed by a single radiologist with LOGIQ S6 (GE Healthcare, USA) ultrasound system.A $12 \mathrm{MHz}$ linear-array transducer was used with ultrasound gel as a coupling medium overall the upper lip. The transducer was applied to this gel layer for obtaining a transverse plane to the lip from the skin surface to the oral mucosa avoiding the air bubbles inclusion between transducer and gel surface. The gel layer for preventing the contact between the lip tissues and the transducer.

In this way, the ultrasound beams are almost perpendicular to the lip. The patients were asked to keep the lip relaxed not contracted in a supine position with centralized head, and the transducer was advanced into the right and left directions from the midline perpendicular to the skin surface while the patient was in a supine position with centralized head. 2D images were obtained to appraise the scar depth and width. The scar borders were sited and measured. The scar was manually located according to its different echogenic state than in normal lip. The scar dimensions were collected on postoperative one week, three weeks, three months and six months respectively.

\section{Statistical Analysis}

All test data was converted and manipulated by using SPSS software program version 20.0. The quantitative data was compared and t test was applied for normally distributed data and Mann-Whitney $\mathrm{U}$ test was done for non-parametric data. Significance level was set at $\mathrm{P} \leq 0.01$. Statistical analysis was performed with IBM ${ }^{\circledR}$ SPSS ${ }^{\circledR}$ Statistics Version 20 for Windows.

\section{RESULTS}

\section{Clinically}

Group I showed better clinical healing with lesser scarring than group II. (Fig.1)

\section{Ultrasonographic results}

Statistically significant difference was found between group I and group II where group II showed higher scar dimensions more than group I in $\mathrm{p}<0.01$ (Table 1), (Fig.2,3) 


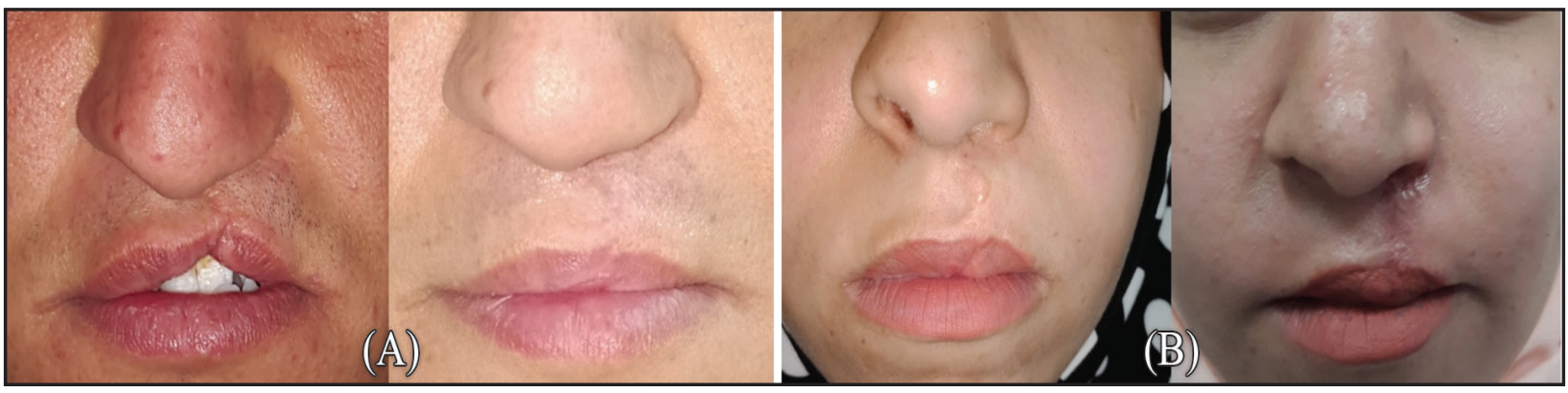

Figure (1) Pre and six months postoperative healing in (A) group I and (B) group II

Table (1): Showing the time effect on width and depth dimensions of studied groups.

\begin{tabular}{|c|c|c|c|c|c|c|c|c|}
\hline \multirow[b]{2}{*}{ Group } & \multirow[b]{2}{*}{ Dimension } & \multirow{2}{*}{$\begin{array}{c}\text { Pre-operative } \\
\text { Mean (SD) }\end{array}$} & \multicolumn{4}{|c|}{ Postoperative } & \multirow[b]{2}{*}{$\mathbf{F}$} & \multirow[b]{2}{*}{$\mathbf{P}$} \\
\hline & & & $\begin{array}{l}\text { After } 1 \\
\text { week }\end{array}$ & $\begin{array}{c}\text { After } 3 \\
\text { weeks }\end{array}$ & $\begin{array}{l}\text { After } 3 \\
\text { months }\end{array}$ & $\begin{array}{l}\text { After } 6 \\
\text { months }\end{array}$ & & \\
\hline \multirow{2}{*}{ Group I } & Width & $0.74(0.1)$ & $0.86(0.1)$ & $0.8(0.1)$ & $0.56(0.05)$ & $0.46(0.1)$ & 2546.48 & $<0.001^{*}$ \\
\hline & Depth & $0.52(0.2)$ & $0.55(0.1)$ & $0.52(0.1)$ & $0.43(0.1)$ & $0.32(0.1)$ & 253.57 & $<0.001^{*}$ \\
\hline \multirow{2}{*}{ Group II } & Width & $1.05(0.2)$ & $1.35(0.3)$ & $1.24(0.2)$ & $0.93(0.04)$ & $0.76(0.04)$ & 680.08 & $<0.001 *$ \\
\hline & Depth & $0.63(0.2)$ & $1.1(0.2)$ & $0.9(0.1)$ & $0.77(0.07)$ & $0.65(0.05)$ & 373.18 & $<0.001 *$ \\
\hline \multicolumn{2}{|c|}{ Pvalue $^{@}$} & $0.008 *$ & $0.009 *$ & $0.005^{*}$ & $<0.001 *$ & $0.001 *$ & & \\
\hline \multicolumn{2}{|c|}{$P$ value\# } & 0.4 & $0.001 *$ & $0.001 *$ & $<0.001^{*}$ & $<0.001 *$ & & \\
\hline
\end{tabular}

@ $p$ value between group 1 and group 2 according to width dimensions

\# $p$ value between group 1 and group 2 according to depth dimensions

*statistically significant difference $p<0.01$

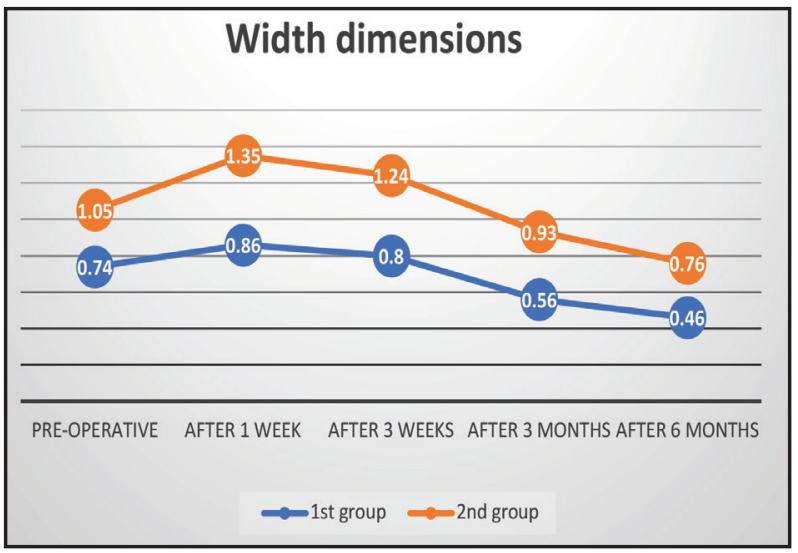

Figure (2) Width dimension in group I and group II

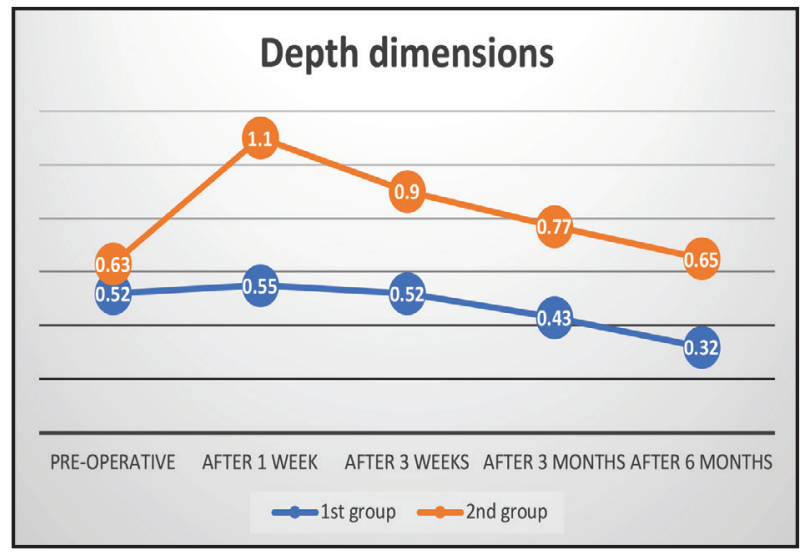

Figure (3) Depth dimension in group I and group II 


\section{DISCUSSION}

The secondary cleft deformity is a mandatory issue that can't be avoided ${ }^{25)}$. After the primary cleft repair, there are variable growth processes that may change theses primary surgical results. So, the correction of these deformities is required for these patients and they are usually more complicated than the primary surgeries ${ }^{(26)}$. The problems related are commonly wide-ranged. So, the choice of a suitable technique to correct them is inspiring ${ }^{(27)}$.

Hence, it is important to perform secondary revision surgery to regain the proper functional and social development ${ }^{28)}$. Scar tissue formation is a multifactorial process with different clinical manifestations. Most of the cleft lip patients have physiological and psychological effects; the scar of the cleft lip doesn't only affect the function but also affects the life quality of the affected individuals ${ }^{(29)}$.

Thus, this study aimed to evaluate the early effect of BM-MSCs injection on scar formation after secondary cleft lip correction. Ten patients, five in each group with a mean age (8-30 years) with unilateral complete or incomplete cleft lip had received only the primary cleft lip repair with post-operative cleft lip scarring and deformities needed secondary cleft lip correction were included in this study. The functional repair method concept was used in all patients where the nasalis muscle and nasolabial muscle bundle were advanced and reattached in the periosteum of the anterior nasal spine to rebuild the nostril sill and gain symmetrical bilateral nostril width. Orbicularis oris muscle was dissected and sutured into its other part on the noncleft side.

BM-MSCs used in this study was prepared by the density gradient centrifugation method technique. It provides a good cellular separation process. Producing a pure, highly viable number of mononuclear cells with little red blood cell and granulocyte contamination with the optimum functional capacity ${ }^{(30)}$. The density gradient separation with immediate transplantation method has several advantages. No invasive enzymatic treatment and the cells are considered minimally handled. Furthermore, immediate BMMNCs transplantation avoids the complications of the quality of the transplanted cells such as reduced viability, dedifferentiation or mutations that may associate in in-vitro culture. Risk of contamination is reduced by controlling the time of cell handling during preparation and culture ${ }^{(24)}$.

In this study, superficial musculoskeletal ultrasound with high resolution and low penetration power $12 \mathrm{MHz}$ with linear array transducer were used ${ }^{(31)}$. The ultrasound allows the noninvasive evaluation of the skin and deep layers; therefore, it can give the anatomical location, the diameters, including depth, and the vascularity ${ }^{(32)}$. It also has been shown to be reproducible and accurate in the determination of the thickness of normal and scarred skin ${ }^{(20)}$. The ultrasound examination was easy, dependent, with no radiation, and easy identification of the lip structure $^{(33)}$.

In this study, we found that there were good clinical results in scar attenuation in group I after six months follow up and that was agreed with some recent clinical studies which reported the effect of bone marrow mesenchymal stem cells on facial scar acne ${ }^{(34)}$ and other experimental studies which introduced a local delivery of bone marrow and adipose-tissue derived MSCs in cutaneous wound healing in a porcine model ${ }^{(35)}$.

Ultrasound results showed that it was statistically significant difference inside each group in both groups at different time periods with scar reduction which indicated that the healing process was continuous and proceeded in the direction of scar reduction across time till six months. It was agreed with the study which stated that the scar reduction remined continues till the end of six months and after six months no more remodeling would occur.

Although, both groups showed decrease in scar dimensions, group I already had preoperative little scar dimension regarding the width that was 
continuous little than group II along all the follow up period which not indictive to the effect of stem cells even with the better clinical results that was presented in this group.

No statistically significant difference was found between both groups regarding the depth while in the postoperative follow up group I showed little dimensions than group II in all periods that may be contributed to the effect of stem cells.

\section{CONCLUSION}

- The bone marrow mesenchymal stem cells injection may have good clinical effect on the healing outcome when injected in secondary cleft lip correction.

- From the clinical results it is recommended to re-evaluate the effect of stem cells in scar formation on large number of patients and comparing between one injection and more than one-time injection techniques.

\section{REFERENCES}

1. He J, Xu H, Wang T, Zhang Y, Dong J, Wei J, et al Simultaneous reconstruction of columella and philtrum using prolabial fl ap combined with Abbe fl ap in secondary bilateral cleft lip and nasal deformity. J CranioMaxillofacial Surg. 2017;1-5.

2. Bertossi D, Corega ÃC, Boccieri A, Procacci P, Mortellaro ÃC, Nocini P. The Anatomical Balance Correction for Secondary Cleft Lip Nasal Deformities. 2016;27:2130-3

3. Alpagan S. Three-Dimensional Soft-Tissue Evaluation in Patients with Cleft Lip and Palate. 2018;8608-20.

4. Bagante I, Akota I. Cleft-related nose deformation evaluation and measurement methods . Literature review. 2015;17:75-83.

5. Perko MA. Secondary Lip Correction in Unilateral Cleft Lips. 1977;5:245-9.

6. Penfold CN, Mumford RA. 70 - Secondary Cleft Surgery. Third Edit. Maxillofacial Surgery. Elsevier Inc.; 1000$1013 \mathrm{p}$.

7. Vass G, Mohos G, Bere Z, Ivan L, Varga J, Piffko J, et al. Secondary correction of nasal deformities in cleft lip and palate patients: surgical technique and outcome evaluation. Head Face Med. 2016;1-5.

8. Kaufman Y, Stal S, Buchanan EP, Wolfswinkel EM, Weathers WM. Cleft Nasal Deformity and Rhinoplasty. 2012;1:184-90.

9. Aydoğmuş S, Kelekçi KH, Şengül M, Demirel E, Karaca Ş, Desdicioğlu R, et al. Factors affecting the development of scar formation in abdominal surgery performed for gynecologic and obstetric conditions. Turkderm. 2017;51:12-7.

10. Wang PH, Huang BS, Horng HC, Yeh CC, Chen YJ. Wound healing. J Chinese Med Assoc. 2018;81:94-101.

11. Kasuya A, Tokura Y. Attempts to accelerate wound healing. J Dermatol Sci. 2014;76:169-72.

12. Chang C, Wallace CG, Hsiao Y, Huang J, Chen Z, Chang $\mathrm{C}$, et al. Clinical evaluation of silicone gel in the treatment of cleft lip scars. Sci Rep. 2018;1-5.

13. Ikebe C, Suzuki K. Mesenchymal Stem Cells for Regenerative Therapy: Optimization of Cell Preparation Protocols. Biomed Res Int. 2014;2014:1-11.

14. Bortolotti F, Ukovich L, Razban V, Martinelli V, Ruozi G, Pelos B, et al. In vivo therapeutic potential of mesenchymal stromal cells depends on the source and the isolation procedure. Stem Cell Reports. 2015;4:332-9.

15. Eng JT, Med R, Mueller D, Tascher G, Ursula M,Knobeloch $\mathrm{D}$, et al. In-depth physiological characterization of primary human hepatocytes in a 3D hollow-fiber bioreactor. J Tissue Eng Regen Med. 2011:90-100.

16. Yoo D, Maxson S, Danilkovitch-Miagkova A, LeRoux MA, Lopez EA. Concise Review: Role of Mesenchymal Stem Cells in Wound Repair. Stem Cells Transl Med. 2012;1:142-9.

17. Isikli C., Hasirci V., Hasirci N. Co-culture in cartilage tissue engineering. J Tissue Eng Regen Med. 2012;6135-43.

18. Domergue S, Bony C, Maumus M, Toupet K, Frouin E, Rigau V, et al. Comparison between stromal vascular fraction and adipose mesenchymal stem cells in remodeling hypertrophic scars. PLoS One. 2016;11:1-16.

19. Julianto I, Rindastuti Y. Topical Delivery of Mesenchymal Stem Cells "Secretomes" in Wound Repair. Acta Med Indones. 2016;48:217-20.

20. Agabalyan NA, Su S, Sinha S, Gabriel V. Comparison between high-frequency ultrasonography and histological assessment reveals weak correlation for measurements of scar tissue thickness. Burns. 2017;43:531-8. 
21. Verhaegen PDHM, van der Wal MBA, Middelkoop E, van Zuijlen PPM. Scar assessment. Handb Burn Reconstr Rehabil 2012;2:69-89.

22. DeJong HM, Abbott S, Zelesco M, Kennedy BF, Ziman MR, Wood FM. The validity and reliability of using ultrasound elastography to measure cutaneous stiffness, a systematic review. Int J Burns Trauma. 2017;7:124-41.

23. Zhang WH, Chen YY, Liu JJ, Liao XH, Du YC, Gao Y. Application of ultrasound imaging of upper lip orbicularis oris muscle. Int J Clin Exp Med. 2015;8:3391-400.

24. Al-Ahmady HH, Abd Elazeem AF, Bellah Ahmed NE moataz, Shawkat WM, Elmasry M, Abdelrahman MA, et al. Combining autologous bone marrow mononuclear cells seeded on collagen sponge with Nano Hydroxyapatite, and platelet-rich fibrin: Reporting a novel strategy for alveolar cleft bone regeneration. J Cranio-Maxillofacial Surg. 2018;46:1593-600.

25. Fan Q, Li Y, Danning Z, Ph D, Zhang B, Chen S, et al. ““ Three-Unit " Muscle Reconstruction in Secondary Cleft Lip Repair. 2015;52:88-95.

26. John J, Usha AM, Aziz M, Achary VR, Krishnan H. Management of Commonly Encountered Secondary Cleft Deformities of Face-A Case Series. 2017;6:1-5.

27. Fürchtgott N, Ruiz RL, Costello BJ. Revision Surgery for Cleft. Third Edit. Oral and Maxillofacial Surgery. Elsevier Inc.; 2019. 609-626 p.
28. Cohn JE, Nyirjesy S, Davis WJ. Repair of a Secondary Cleft Lip Deformity With the Abbé Flap in a Pediatric Patient. Ear, Nose Throat J. 2019;98:265-7.

29. Zhang DZ, Liu F, Xiao WL, Cong WW. Longitudinal Study of Scar Hyperplasia Formation Following Cleft Lip Wound Healing. J Craniofac Surg. 2018;29:211-5.

30. Pierini M, Dozza B, Lucarelli E, Tazzari PL, Ricci F, Remondini D, et al. Efficient isolation and enrichment of mesenchymal stem cells from bone marrow. Cytotherapy. 2012;14:686-93.

31. Fan D, Xia Q, Wu S, Ye S, Liu L, Wang W, et al. Mesenchymal stem cells in the treatment of Cesarean section skin scars: Study protocol for a randomized, controlled trial. Trials. 2018;19:4-11.

32. Lobos N, Wortsman X, Valenzuela F, Alonso F. Color Doppler Ultrasound Assessment of Activity in Keloids. Dermatologic Surg. 2017;43:817-25.

33. Matic DB, Frcsc P, Power SM. Correction of the Cleft Lip Lateral Bulge Deformity Using Anatomic Muscle Repair. 2011;22:514-9.

34. Ibrahim ZA, Eltatawy RA, Ghaly NR, Abd El-Naby NM, Abou El Fetouh HM, Abd Elateef AE, et al. Autologus bone marrow stem cells in atrophic acne scars: A pilot study. J Dermatolog Treat. 2015;26:260-5.

35. Hanson SE, Kleinbeck KR, Cantu D, Kim J, Michael L, Faucher LD, et al. Healing in a Porcine Model. 2014;10:1-20. 